\title{
PELAKSANAAN DIVERSI BAGI ANAK YANG MELAKUKAN TINDAK PIDANA DI WILAYAH HUKUM KEPOLISIAN RESOR CILACAP ${ }^{1}$ Oleh: KUSHANINDYO NORYA PRABOWO
}

\begin{abstract}
The handling of J uvenile J ustice, diversion or peace efforts by bringing together victims and offenders and their families shall be carried out by law enforcement officials. By 2015 the number of cases of children as much as 5 kasus.J umlah Cilacap Police diversion is done yet, but it has been done in the Police Central Cilacap. Therefore it is interesting to study.

This study aims to investigate the implementation of diversion for children who commit criminal offenses in Cilacap Police J urisdiction can contribute ideas and Science regarding the juvenile justice system. It is also to contribute to society on the implementation of diversion for children who commit criminal offenses in the police station jurisdiction Cilacap. To achieve these objectives, the authors use the method of juridical sociological.

The study states that, implementation of diversion for children who commit criminal offenses in the jurisdiction of Police Cilacap done in several stages, the preparatory phase of diversion, diversion deliberation, and diversion agreement. Preliminary stage diversion process is done by calling the interested parties. Diversion is done with a preparation that call the various parties, namely the Son and the parent/guardian or consort, Victim and/or parent/guardian, supervisor of community, social worker professionals, community representatives, That the parties deemed necessary to be involved in deliberations versioned. Phase deliberations diversions opened by facilitator diversion with the introduction of the parties present, convey the intent and purpose of deliberation diversion. Diversion Stage results must be submitted by the employer directly responsible for all levels of examination (meaning in the process of investigation, prosecution and court examination) to the District Court for Determination issued and institutionally competent authority issuing Determination is the Chairman of Cilacap District Court. Not all cases of children in police Resort Cilacap applied versioned, only to cases that can be reconciled only do versioned. Constraints in the implementation of diversion for children who commit criminal offenses in the law region resor Cilacap Police, driven by factors thats, factor law enforcement, lack of understanding of law enforcement officers (police) about the meaning and purpose of diversion and the low awareness of law enforcement to implement a diversion to make the child offender processed up to the court, so it ended up in jail.
\end{abstract}

Keywords: justice system child, criminal, law enforcement

\begin{abstract}
Abstrak
Penanganan Peradilan Anak, upaya diversi atau perdamaian dengan mempertemukan korban dan pelaku beserta keluarganya wajib dilakukan oleh aparat penegak hukum. Pada tahun 2015 jumlah kasus anak sebanyak 5 kasus.Jumlah diversi yang dilakukan Polres Cilacap belum ada, namun pernah dilakukan di Polsek Cilacap Tengah. Oleh sebab itu menarik untuk dikaji.

Penelitian bertujuan untuk mengetahui pelaksanaan diversi bagi anak yang melakukan tindak pidana di Polres Cilacap, memberikan sumbangan pemikiran dan Ilmu pengetahuan mengenai sistem peradilan pidana anak. Selain itu juga untuk memberikan kontribusi bagi masyarakat tentang pelaksanaan diversi bagi anak yang melakukan tindak pidana di Polres Cilacap. Untuk mencapai tujuan tersebut, maka penulis menggunakan metode yuridis sosiologis.

Hasil penelitian menyatakan pelaksanaan diversi bagi anak yang melakukan tindak pidana di Polres Cilacap dilakukan dengan beberapa tahap yaitu tahap persiapan diversi, musyawarah diversi, dan kesepakatan diversi. Diversi dilakukan dengan suatu persiapan
\end{abstract}

\footnotetext{
1 Judul diajukan dalam Jurnal Idea Hukum, Magister Hukum UNSOED
} 
335 | J urnal Idea Hukum

Vol. 2 No. 2 Oktober 2016

Magister Hukum Fakultas Hukum Universitas J enderal Soedirman

yaitu pemanggilan berbagai pihak yaitu Anak dan orang tua/wali atau pendampingnya, Korban dan/atau orang tua/walinya, Pembimbing kemasyarakatan, Pekerja sosial professional, Perwakilan masyarakat, Pihak-pihak terkait lainnya. Tahap musyawarah diversi dibuka oleh fasilitator diversi dengan perkenalan para pihak yang hadir, menyampaikan maksud dan tujuan musyawarah diversi. Tahap hasil Diversi harus disampaikan oleh atasan langsung yang bertanggung jawab di setiap tingkat pemeriksaan. kepada Pengadilan Negeri untuk diterbitkan Penetapan. Tidak semua kasus anak di Resort Cilacap diterapkan diversi, hanya terhadap kasus yang dapat didamaikan saja. Kendala dalam pelaksanaan diversi bagi anak yang melakukan tindak pidana di Polres Cilacap, didorong oleh faktor-faktor Penegak Hukum, Kurangnya pemahaman aparat penegak hukum (kepolisian) tentang makna dan tujuan diversi serta rendahnya kesadaran penegak hukum untuk menerapkan diversi menjadikan anak pelaku tindak pidana diproses hingga ke Pengadilan, sehingga berakhir di penjara.

Kata kunci: peradilan anak, tindak pidana, penegakan hukum

\section{A. Latar Belakang Masalah}

Dalam penanganan Peradilan Anak, upaya diversi atau perdamaian dengan mempertemukan korban dan pelaku beserta keluarganya wajib dilakukan oleh aparat penegak hukum. Meski demikian pihak keluarga juga memiliki hak untuk menolak upaya diversi dan polisi akan membuat berita acara penolak diversi.

$\mathrm{Hal}$ itu diungkapkan oleh KBO Satreskrim Polres Cilacap-IPTU Bambang Listiono dalam kegiatan Advokasi Penguatan Jejaring Penanganan Anak yang Berkonflik dengan Hukum di Kabupaten Cilacap tahun 2013 di Pendopo Kecamatan Cilacap Selatan. ${ }^{2}$

Permasalahan lain yang timbul yaitu anak memang harus dilindungi demi tumbuh kembangnya di masa yang akan datang, namun demikian bagaimana apabila anak tersebut telah melakukan tindak pidana dalam batas

\footnotetext{
${ }^{2}$ NN, Polisi Wajib Laksanakan Diversi dalam Peradilan Anak, http://yesfmcilacap.com/polisi wajib laksanaka n diversi dalam peradilan anak berita3044.ht ml, diakses pada tanggal 28 Desember 2014.
}

kewajiaran. Hal ini tentunya menjadi konflik bagi aparat penegak hukum, karena melalui Undang-Undang 11 Tahun 2012 tentang Sistem Peradilan Pidana, hakim dituntut untuk memberikan kearifan dan hukuman yang edukatif, namun disisi lain prevensi general yaitu terlindunginya kepentingan masyarakat nantinya akan terabaikan.

Pada tahun 2014 jumlah kasus anak di Polres Cilacap berjumlah 28 Kasus, dan yang dilimpahkan ke Jaksa guna dilakukan penuntutan berjumlah 16 kasus (pelakunya anak) dan sisanya masih tahap penyidikan. Pada tahun 2015 jumlah kasus anak sebanyak 5 kasus. Jumlah diversi yang dilakukan Polres Cilacap belum ada, namun pernah dilakukan di Polsek Cilacap Tengah. ${ }^{3} \mathrm{Hal}$ ini tentunya menjadi suatu pertanyaan, apakah polisi tidak menerapkan diversi, ataukah persepsi tentang diversi berbeda-beda di setiap instansi kepolisian. Hal ini tentunya

\footnotetext{
${ }^{3}$ Survey Pendahuluan dan wawancara dengan Eny Marisa, Anggota Unit (Pelayanan Perempuan dan Anak) PPA Kepolisian Resort Cilacap, 13 Februari 2014.
} 
kembali kepada kualitas Kepolisian tersebut dalam menerapkan diversi bagi anak yang melakukan tindak pidana.

\section{B. Perumusan Masalah}

Berdasarkan latar belakang masalah di atas, maka dapat dirumuskan permasalahan:

1. Bagaimana pelaksanaan diversi bagi anak yang melakukan tindak pidana di Wilayah Hukum Polres Cilacap?

2. Apa yang menjadi kendala dalam pelaksanaan diversi bagi anak yang melakukan tindak pidana di Wilayah Hukum Polres Cilacap?

\section{Metode Penelitian}

Metode Pendekatan : yuridis sosiologis

Tipe Penelitian :

Sumber data :

Lokasi Penelitian :

Metode Pengumpulan Data :

Teknik Penyajian Data :

Analisa Data :

\section{Hasil dan Pembahasan}

1. Pelaksanaan Diversi Bagi Anak Yang Melakukan Tindak Pidana Di Wilayah Hukum Polres Cilacap

Pelaksanaan diversi anak

di Kepolisian Resort Cilacap dilakukan dengan tahap sebagai berikut:

a. Persiapan Diversi

Pada tahap pendahuluan proses diversi dilakukan dengan memanggil para pihak yang berkepentingan dan pihak yang diatur oleh Undang Undang No. 11 Tahun 2012 Tentang Sistem Peradilan Pidana Anak. Diversi dilakukan dengan suatu persiapan yaitu pemanggilan berbagai pihak yaitu Anak dan orang tua/wali atau pendampingnya, Korban dan/atau orang tua/walinya, Pembimbing kemasyarakatan, Pekerja sosial professional, Perwakilan masyarakat, Pihakpihak terkait lainnya yang dipandang perlu untuk dilibatkan dalam musyawarah diversi.

b. Tahapan Musyawarah Diversi.

Musyawarah Diversi dipimpin oleh Penyidik sebagai fasilitator dan Pembimbing Kemasyarakatan sebagai wakil fasilitator. Musyawarah Diversi dihadiri oleh Anak dan/atau orang tua/Wali, korban, atau Anak Korban dan/atau orang tua/Wali, dan/atau Pekerja Sosial Profesional. Musyawarah Diversi dapat melibatkan masyarakat.

Musyawarah diversi dibuka oleh fasilitator diversi dengan perkenalan para pihak yang hadir, menyampaikan maksud dan tujuan musyawarah diversi, serta tata tertib musyawarah untuk disepakati oleh para pihak yang hadir. Fasilitator diversi menjelas kan fungsi fasilitator diversi. Fasilitator diversi menjelaskan tentang ringkasan 
337 | J urnal Idea Hukum

Vol. 2 No. 2 Oktober 2016

Magister Hukum Fakultas Hukum Universitas J enderal Soedirman

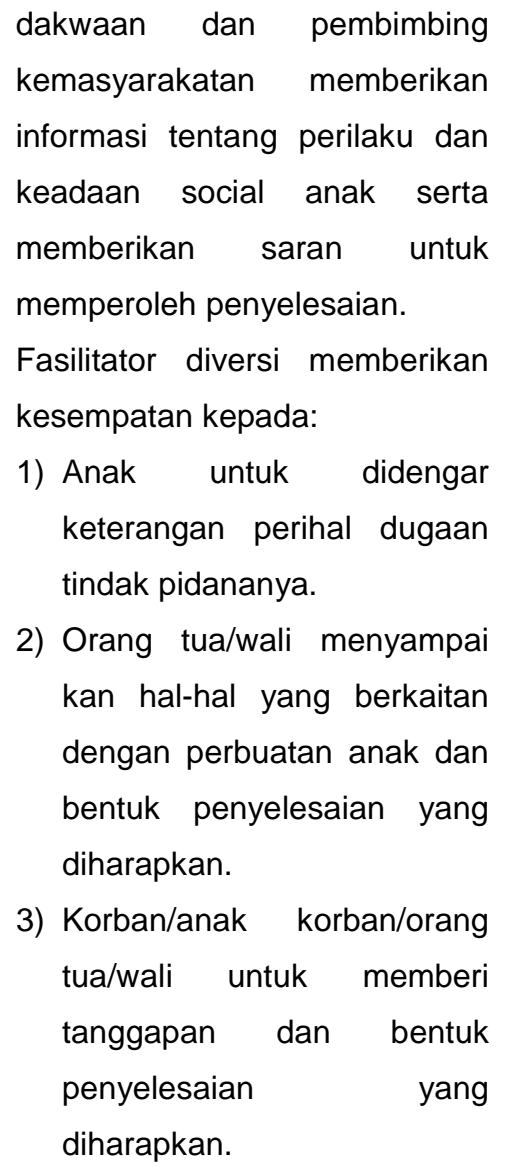

1) Anak untuk didengar keterangan perihal dugaan tindak pidananya.

2) Orang tua/wali menyampai kan hal-hal yang berkaitan dengan perbuatan anak dan bentuk penyelesaian yang diharapkan.

3) Korban/anak korban/orang tua/wali untuk memberi tanggapan dan bentuk penyelesaian yang diharapkan.

Pasal 17 Peraturan Pemerintah Republik Indonesia Nomor 65 Tahun 2015 Tentang Pedoman Pelaksanaan Diversi Dan Penanganan Anak Yang Belum Berumur 12 (Dua Belas) Tahun menyatakan bahwa, dalam hal proses musyawarah Diversi tidak mencapai kesepakatan, Penyidik membuat laporan dan berita acara proses Diversi. Penyidik mengirim kan berkas perkara kepada Penuntut Umum serta melanjutkan proses peradilan pidana. Dalam hal musyawarah Diversi sebagai- mana dimaksud dalam Pasal 16 mencapai kesepakatan, Surat Kesepakatan
Diversi ditandan- tangani oleh Anak dan/atau orang tua/Wali, korban, Anak Korban dan/atau orang tua/Wali, Penyidik, Pembimbing Kemasyarakatan, dan Pekerja Sosial Profesional. Seluruh proses pelaksanaan Diversi tersebut dicatat dalam berita acara Diversi.

c. Kesepakatan Diversi

Musyawarah diversi dicatat dalam berita acara diversi dan ditandatangani oleh fasilitator diversi. Kesepakatan diversi ditandatangani oleh para pihak dan dilaporkan kepada Ketua Pengadilan oleh fasilitator diversi. Dalam hal Diversi mencapai kesepakatan, Penyidik menyampai kan Surat Kesepakatan Diversi dan berita acara Diversi kepada atasan langsung Penyidik. Dalam jangka waktu paling lama 3 (tiga) hari terhitung sejak tanggal dicapainya kesepakatan Diversi, atasan langsung Penyidik mengirimkan Surat Kesepakatan Diversi dan berita acara Diversi kepada Ketua Pengadilan Negeri untuk memper- oleh penetapan.

Pasal 20 PP Nomor 65 Tahun 2015 Tentang Pedoman Pelaksana an Diversi Dan Penanganan Anak Yang Belum Berumur 12 (Dua Belas) Tahun menyatakan bahwa, Ketua Pengadilan Negeri mengeluarkan penetapan kesepakatan 
Diversi dan sekaligus menetapkan status barang bukti dalam jangka waktu paling lama 3 (tiga) hari terhitung sejak tanggal diterimanya Surat Kesepakatan Diversi dan berita acara Diversi. Penetapan di- sampaikan kepada Penyidik dan Pembimbing Kemasyarakatan da- lam jangka waktu paling lama 3 (tiga) hari terhitung sejak tanggal penetapan.

Penyidik meminta para pihak untuk melaksanakan kesepakatan Diversi setelah menerima penetap- an. Atasan langsung Penyidik me lakukan pengawasan terhadap pelaksanaan kesepakatan Diversi. Pembimbing Kemasyarakatan me lakukan pendampingan, pembim- bingan, dan pengawasan pelaksa- naan kesepakatan Diversi.

Dalam hal diperlukan, Pembim bing Kemasyarakatan dapat me laksanakan rehabilitasi dan reinte grasi sosial terhadap Anak, bekerja sama dengan lembaga terkait. Dalam hal diperlukan, Pekerja Sosial Profesional dapat melak- sanakan rehabilitasi dan reintegrasi sosial terhadap Anak Korban, bekerja sama dengan lembaga terkait. Pembimbing Kemasyarakat an menyusun laporan pelaksanaan kesepakatan Diversi. Laporan me- ngenai pelaksanaan kesepakatan Diversi, disampaikan oleh Pem- bimbing Kemasyarakatan kepada atasan langsung Penyidik. Laporan disampaikan secara ringkas dalam jangka waktu paling lama 1 x 24 (satu kali dua puluh empat) jam terhitung sejak kesepakatan Diversi selesai dilaksanakan. Laporan ke- masyarakatan disampaikan secara lengkap dalam jangka waktu paling lama 3 x 24 (tiga kali dua puluh empat) jam terhitung sejak kesepakatan Diversi selesai dilaksanakan.

Adapun hasil kegiatan rapat diversi di Polres Cilacap antara lain:

a. Kedua belah fihak saling memaafkan dan berjanji tidak akan diproses secara hukum.

b. Orang tua pelaku berjanji dan bersedia mengawasi dan menjaga, tingkah laku dan sikap anaknya di masyarakat, dan sanggup memberikan pendidik- an yang sebaikbaiknya.

c. Pelaku masih status pelajar dan masih dibangku sekolah.

d. Pihak yang terkarit dalam rapat menyetujui bahwa pelaku dapat dilakukan Diversi.

Hasil Diversi harus disampaikan oleh atasan langsung yang bertanggung jawab disetiap tingkat pemeriksaan (artinya dalam proses penyidikan, penuntutan maupun pemeriksaan 
339 | J urnal Idea Hukum

Vol. 2 No. 2 Oktober 2016

Magister Hukum Fakultas Hukum Universitas J enderal Soedirman

dipersidangan) ke- pada

Pengadilan Negeri untuk

diterbitkan Penetapan dan secara

institusional pejabat yang ber-

wenang menerbitkan Penetapan

adalah Ketua Pengadilan Negeri

didaerah hukumnya. Kegiatan

diversi dilakukan mengingat

undang -undang sistem peradilan

pidana anak UU No. 11 Tahun

2012, bahwa perkara pelaku

tindak pidana anak dapat

dilakukan diversi yaitu pengalian

penyelesaian perkara anak dari

proses peradilan pidana ke

proses diluar proses peradilan

pidana. Setelah ada ke sepakatan

perkaranya di diversi terus

dibuatkan surat keputusan diversi,

selanjutnya diajukan ke

Pengadilan Negeri Cilacap untuk

dilakukan penetapan keputusan

Diversi.

Dalam hal diperlukan, Pem

bimbing Kemasyarakatan dapat melaksanakan rehabilitasi dan reintegrasi sosial terhadap Anak, bekerja sama dengan lembaga terkait. Dalam hal diperlukan, Pekerja Sosial Profesional dapat melaksanakan rehabilitasi dan reintegrasi sosial terhadap Anak Korban, bekerja sama dengan lembaga terkait. Pembimbing Kemasyarakatan menyusun laporan pelaksanaan

kesepakatan Diversi. Laporan mengenai pelaksanaan kesepakat an Diversi, disampaikan oleh Pem bimbing Kemasyarakatan kepada atasan langsung Penyidik. Laporan disampaikan secara ringkas dalam jangka waktu paling lama 1 × 24 (satu kali dua puluh empat) jam terhitung sejak kesepakatan Diversi selesai dilaksanakan. Laporan kemasyarakatan disampaikan secara lengkap dalam jangka waktu paling lama $3 \times 24$ (tiga kali dua puluh empat) jam terhitung sejak kesepakatan Diversi selesai dilaksanakan.

Penyidik menerbitkan surat ketetapan penghentian penyidikan:

a. dalam jangka waktu paling lama 3 (tiga) hari terhitung sejak tanggal diterimanya surat pene tapan pengadilan, jika kesepakat an Diversi berbentuk perdamai an tanpa ganti kerugian atau penyerahan kembali Anak kepada orang tua/Wali;

b. dalam jangka waktu paling lama 5 (lima) hari terhitung sejak tanggal kesepakatan Diversi selesai dilaksanakan, jika kese- pakatan Diversi berupa pemba- yaran ganti kerugian, pengem- balian pada keadaan semula, atau pelayanan masyarakat;

c. dalam jangka waktu paling lama 5 (lima) hari terhitung sejak tanggal kesepakatan Diversi selesai dilak- sanakan, jika 


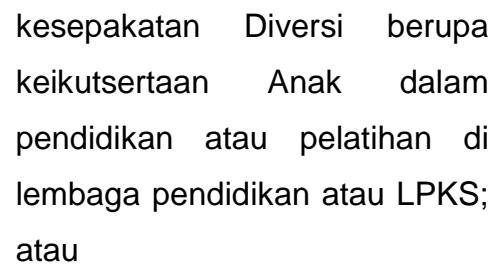

d. dalam jangka waktu paling lama 5 (lima) hari terhitung sejak tanggal seluruh kesepakatan Diversi selesai dilaksanakan.

Surat ketetapan penghentian penyidikan sekaligus memuat penetapan status barang bukti sesuai dengan penetapan Ketua Pengadilan Negeri setempat. Surat ketetapan penghentian penyidikan dikirimkan kepada Penuntut Umum beserta laporan proses Diversi dan berita acara pemeriksaan dengan tembusan kepada Anak dan orang tua/Wali, korban, Anak Korban dan/atau orang tua/Wali, Pembim- bing Kemasyarakatan, Pekerja So- sial Profesional, dan Ketua Pengadilan Negeri setempat.

Dalam hal kesepakatan Diversi tidak dilaksanakan dalam jangka waktu yang telah ditentukan, Pem- bimbing Kemasyarakatan melapor- kan secara tertulis kepada atasan langsung Penyidik untuk ditindaklanjuti dalam proses peradilan pidana dengan tembusan kepada Ketua Pengadilan Negeri setempat. Penyidik menindaklanjuti laporan dalam jangka waktu paling lama 7 (tujuh) hari terhitung sejak tanggal laporan diterima. Penyidik mengirimkan berkas perkara kepada Penuntut Umum serta melanjutkan proses peradilan pidana.

Kesepakatan Diversi tanpa persetujuan korban, dilaksanakan melalui musyawarah yang dipimpin oleh Penyidik sebagai fasilitator dan Pembimbing Kemasyarakatan se- bagai wakil fasilitator serta dihadiri oleh Anak dan orang tua/Walinya. Musyawarah dapat melibatkan tokoh masyarakat. Kesepakatan Diversi dirumuskan dalam Surat Kesepakatan Diversi yang ditanda tangani oleh Anak dan/atau orang tua/Wali, Penyidik, dan Pembimbing Kemasyarakatan. Seluruh proses pelaksanaan Diversi dicatat dalam berita acara Diversi.

Kasus-kasus $\mathrm{ABH}$ yang dibawa dalam proses peradilan ada- lah kasus kasus yang serius saja, itu juga harus selalu mengutama- kan prinsip kepentingan terbaik bagi anak, serta proses penghukuman adalah jalan terakhir (Ultimum Remedium) dengan tetap tidak mengabaikan hak hak anak. Diluar itu kasus kasus anak dapat di- selesaikan melalui mekanisme non formal yang didasarkan pada pe- doman yang baku. Bentuk pena- nganan non formal dapat dilakukan dengan diversi 
341 | J urnal Idea Hukum

Vol. 2 No. 2 Oktober 2016

Magister Hukum Fakultas Hukum Universitas J enderal Soedirman

sebagaimana proses mediasi

yang difasilitasi oleh penegak

hukum pada setiap tingkat untuk

mencapai keadilan restoratif yang

dapat diselesaikan dengan

mewajibkan anak yang

berhadapan dengan hukum untuk

mengikuti pendidikan atau

pelatihan pada lembaga tertentu

seperti berupa tindakan lainnya

yang dilakukan dengan pemulihan

bagi anak serta korban, ataupun

jika terpaksa terjadi peng

hukuman hak hak anak tidak

boleh diabaikan. Sehingga pada

akhirnya penanganan non-formal

dapat ter laksana dengan baik jika

diimbangi dengan upaya

menciptakan sistem peradilan

yang kondusif.

Diversi dapat juga digambarkan sebagai suatu sistem dimana fasilitator mengatur proses penyelesaian pihak-pihak yang bertikai untuk mencapai penyelesaian yang memuaskan sebagai keadilan restoratif. Tradisi dan mekanisme musyawarah mufakat merupakan wujud nyata dalam memperkuat hukum yang hidup dalam masya- rakat sejak dulu. Dengan demikian, inti dari keadilan restoratif adalah penyembuhan, pembelajaran moral, partisipasi dan perhatian masya-rakat, dialog, rasa memaafkan, tanggungjawab dan membuat peru- bahan, yang semuanya itu meru-pakan pedoman bagi proses restorasi
dalam perspektif keadilan
restoratif.

Pelaksanaan diversi membe- rikan dukungan terhadap proses perlindungan terhadap anak yang berkonflik dengan hukum. Sesuai dengan prinsip utama dari diversi, mempunyai dasar kesamaan yaitu menghindarkan pelaku tindak pidana dari sistem peradlan pidana formal dan memberikan kesempatan anak pelaku untuk menjalankan sanksi alternatif pidana penjara.

$$
\text { Penyelesaian tidak }
$$

pidana yang dilakukan oleh anak dengan kebijakan diversi membawa parti-sipasi masyrakat dan mediator sebagai salah satu komponen penting selain aparat penegak hukum sistem peradilan pidana. Peran masyarakat di sini adalah memberikan aspirasinya dalam pelaksanaan proses restorative justice yaitu dengan mengusaha kan agar dapat mengembalikan tatanan masyarakat yang ter ganggu akibat pelanggaran yang dilakukan pelaku dan mengemba-likan korban dan pelaku ke dalam wadahnya semula yaitu keluarga dan lingkungannya.

Pelaksanaan diversi bagi anak yang melakukan tindak 
pidana di wilayah hukum Polres

Cilacap dila-kukan dengan beberapa tahap yaitu tahap persiapan diversi, musya-warah diversi, dan kesepakatan diversi. Tahap pendahuluan/ per- siapan proses diversi dilakukan dengan memanggil para pihak yang berkepentingan dan pihak yang diatur oleh Undang Undang No.11 Tahun 2012 Tentang Sistem Peradilan Pidana Anak. Diversi dilakukan dengan suatu persiapan yaitu pemanggilan berbagai pihak yaitu Anak dan orang tua/wali atau pendampingnya, Korban dan/atau orang tua/walinya, Pembimbing kemasyarakatan, Pekerja sosial professional, Perwakilan masyara kat, Pihak-pihak terkait lainnya yang dipandang perlu untuk dilibatkan dalam musyawarah diversi. Musya- warah diversi dibuka oleh fasilitator diversi dengan perkenalan para pihak yang hadir, menyampaikan maksud dan tujuan musyawarah diversi. Hasil Diversi harus disampaikan oleh atasan langsung yang bertanggung jawab disetiap tingkat pemeriksaan (artinya dalam proses penyidikan, penuntutan maupun pemeriksaan dipersidangan) kepa-da Pengadilan Negeri untuk diterbitkan Penetapan dan secara institusional pejabat yang berwenang menerbitkan Penetapan ada- lah Ketua Pengadilan Negeri Cilacap.

2. Kendala Pelaksanaan Diversi Bagi Anak Yang Melakukan Tindak Pidana Di Wilayah Hukum Polres Cilacap

Secara konsepsional arti pene-gakan hukum terletak pada kegiat- an menyerasikan hubungan nilai-nilai yang terjabarkan di dalam kai-dahkaidah yang mantap dan meng ejawantah serta sikap tindak se bagai rangkaian pejabaran nilai tahap akhir, untuk menciptakan, memelihara, dan mempertahankan kedamaian pergaulan hidup. ${ }^{4}$ Soer- jono Soekanto menyatakan bahwa masalah penegakan hukum sebenarnya terletak pada faktor-faktor yang mungkin mempengaruhinya seperti faktor Hukum/undang-un dang, faktor penegak hokum, faktor sarana atau fasilitas, manusia dan faktor kebudayaan. ${ }^{5}$

Faktor-faktor pelaksanaan diversi bagi anak yang melakukan tindak pidana di wilayah hukum Polres Cilacap adalah sebagai berikut:

a. Faktor Penegak Hukum

Ruang lingkup suatu pene- gakan hukum adalah sangat luas, karena mencakup

\footnotetext{
${ }^{4}$ Soerjono Soekanto, 2011, Faktor-Faktor Yang Mempengaruhi Penegakan Hukum, PT.Raja Grafindo Persada, Jakarta hal. 5

5 Ibid, hal. 8
} 
343 | J urnal Idea Hukum

Vol. 2 No. 2 Oktober 2016

Magister Hukum Fakultas Hukum Universitas J enderal Soedirman

mereka yang secara langsung

maupun tidak langsung

berkecimpung dalam

penegakan hukum. ${ }^{6}$ Un- tuk

membatasi hal yang luas ter-

sebut maka mengartikan pene-

gakan hukum skala subjektif

pe-negakan hukum haruslah

ter-tentu yaitu polisi, jaksa,

hakim, dan pengacara.

Kurangnya pemahaman aparat penegak hukum (kepolisian) tentang makna dan tujuan diversi serta rendahnya kesa-daran penegak hukum untuk me nerapkan diversi menjadikan anak pelaku tindak pidana dipro-ses hingga ke Pengadilan, se hingga berakhir di penjara. Fak- tor penegak hukum memegang peran dominan. ${ }^{7}$

b. Faktor Sarana atau Fasilitas

Walaupun keadilan Restoratif Justice dan Diversi sudah mulai dikenal sebagai alternatif penanganan anak berhadapan dengan hukum dari peradilan pida na dan mulai mendapatkan dukung an banyak pihak masih banyak hambatan yang dihadapi oleh sistem peradilan anak. Terbatas nya sarana dan prasarana pena nganan anak berhadapan dengan hukum selama proses pengadilan (pra dan pasca putusan pengadilan).
Tanpa adanya fasilitas terten-tu, maka tidak mungkin penegakan hukum akan berlangsung dengan lancar. Sarana atau fasilitas ter-sebut antara lain mencakup tenaga manusia yang berpendidikan dan terampil, organisasi yang baik, per-alatan yang memadai, keuangan yang cukup dan lainnya. ${ }^{8} \quad$ Penyidik /penyidik pembantu dalam melaksa-nakan tugasnya seharusnya dileng kapi berbagai sarana dan fasilitas berupa penyediaan fasilitasfasilitas untuk mendukung pelaksanaan tugasnya.

c. Faktor Masyarakat

Penegakan hukum berasal dari masyarakat dan bertujuan untuk mencapai kedamaian di dalam masyarakat. Oleh karena itu dipandang dari sudut tertentu, maka masyarakat dapat mempengaruhi penegakan hukum tersebut. Terdapat beberapa faktor masyarakat yang menimbulkan hambatan bagi pene-gakan hukum antara lain:

1) Tidak mengetahui atau tidak menyadari, apabila hak-hak mereka dilanggar atau terganggu,

2) Tidak mengetahui akan adanya upaya-upaya hukum untuk melindungi kepentingankepentingannya,

3) Tidak berdaya untuk memanfaatkan upaya-upaya hukum karena faktor-faktor keuangan, psikis, sosial atau politik.

\footnotetext{
${ }^{8}$ Ibid, hal. 37
} 
4) Tidak mempunyai pengalaman menjadi anggota organisasi yang memperjuangkan kepentingan-kepentingannya,

5) Mempunyai pengalamanpengalaman kurang baik di dalam proses interaksi dengan pelbagai unsur kalangan hukum formal. $^{9}$

Pemahaman masyarakat akan perdamaian khususnya orang tua korban dalam menyelesaikan masalah. Hal ini tentunya mengakibatkan tidak tercapainya kesepakatan antar para pihak baik pelaku dan korban. Sebagai salah satu akibat negatif dari pan- dangan atau anggapan bahwa hukum adalah hukum positif tertulis belaka adalah adanya kecenderungan yang kuat sekali bahwa satu-satunya tugas hukum adalah adanya kepastian hukum. Dengan adanya kecenderung an untuk lebih menekankan pada ke- pastian hukum belaka, maka akan muncul anggapan yang kuat sekali bahwa satu-satunya tujuan hukum adalah ketertiban. Lebih mementing kan ketertiban berarti lebih menekan kan pada kepentingan umum, sehing ga timbul gagasan-gagasan yang kuat bahwa semua bidang kehidupan akan dapat diatur dengan hukum tertulis. Kecenderungankecenderungan yang legistis tersebut pada akhimya akan menemukan kepuasan pada lahirnya perundangundangan yang belum tentu berlaku secara sosiologis. Di lain pihak

${ }^{9}$ Ibid., hal. 56-57 kecenderungan-kecenderungan

tersebut kadang-kadang menganggap bahwa terjemahanterjemahan tidak resmi dari perundang-undangan zaman Hindia Belanda, secara yuridis telah berlaku. ${ }^{10}$

\section{E. Simpulan Dan Saran}

\section{Simpulan}

Berdasarkan hasil peneltian dan pembahasan yang dilakukan oleh penulis, maka dapat diambil suatu simulan sebagai berikut:

a. Pelaksanaan diversi bagi anak yang melakukan tindak pidana di wilayah hukum Polres Cilacap dilakukan dengan beberapa tahap yaitu:

1) Tahap persiapan diversi, musyawarah diversi, dan kesepakatan diversi. Tahap pendahuluan/persiapan proses diversi dilakukan dengan memanggil para pihak yang berkepentingan dan pihak yang diatur oleh Undang Undang No.11 Tahun 2012 Tentang Sistem Peradilan Pidana Anak. Diversi dilakukan dengan suatu persiapan yaitu pemanggilan berbagai pihak yaitu Anak dan orang tua/wali ataupendampingnya, Korban dan/atau orang tua/ walinya, Pembimbing kemasyarakatan, Pekerja sosial professional, Perwakilan ma-

\footnotetext{
${ }^{10}$ Ibid., hal. 57
} 
345 | J urnal Idea Hukum

Vol. 2 No. 2 Oktober 2016

Magister Hukum Fakultas Hukum Universitas J enderal Soedirman

syarakat, Pihak-pihak terkait lainnya yang dipandang perlu untuk dilibatkan dalam musyawarah diversi.

2) Tahap musyawarah diversi dibuka oleh fasilitator diversi dengan perkenalan para pihak yang hadir, menyampaikan maksud dan tujuan musyawarah diversi.

3) Tahap hasil Diversi harus disampaikan oleh atasan langsung yang bertanggung jawab disetiap tingkat pemeriksaan (artinya dalam proses penyidikan, penuntutan maupun pemeriksaan dipersidangan) kepada $\mathrm{Pe}$ ngadilan Negeri untuk diterbit kan Penetapan dan secara institusional pejabat yang berwenang menerbitkan $\mathrm{Pe}$ netapan adalah Ketua Pengadilan Negeri Cilacap. Tidak semua kasus anak di Kepolisian Resort Cilacap diterapkan diversi, hanya terhadap kasus-kasus yang dapat maikan saja dilakukan diversi.

b. Kendala dalam pelaksanaan diversi bagi anak yang melakukan tindak pidana di Wilayah Hukum Polres Cilacap, didorong oleh faktor-faktor sebagai berikut :

1) Faktor Penegak Hukum

Kurangnya

pemaham an aparat penegak

hukum

(kepolisian) tentang mak-

na dan tujuan diversi

serta rendahnya

kesadaran pe-negak

hukum untuk me-

nerapkan diversi menjadi

kan anak pelaku tindak

pidana diproses hingga

ke Pengadilan, sehingga

ber akhir di penjara.

2) Faktor Sarana Dan

Prasarana

Penyidik/penyidi

$k$ pem-bantu dalam

melak-sanakan tugasnya

belum dilengkapi sarana

dan fasilitas berupa

penyedia an fasilitas-

fasilitas untuk mendukung

pelaksanaan tugasnya.

3) Faktor Masyarakat dan

Keluarga Korban

Pemahaman

masyarakat terutama keluarga korban akan perdamaian atau diversi dalam menyelesaikan ma-salah. Hal ini tentunya mengakibatkan tidak tercapainya kesepakatan antar para pihak baik pelaku dan korban.

\section{Saran}

a. Sebaiknya diberikan pembekalan dan pemahaman kepada aparat penegak hukum di Kabupaten Cilacap (kepo- 
lisian) tentang makna dan tujuan diversi.

b. Perlunya pemahaman dari keluarga baik pelaku maupun korban akan perdamaian khususnya orang tua korban dalam menyelesaikan masalah.

\section{DAFTAR PUSTAKA}

Soekanto, Soerjono. 2011. FaktorFaktor Yang Mempengaruhi Penegakan Hukum.PT.Raja Grafindo Persada. Jakarta.

Wahyudi, Setya. 2011. Implementasi Ide Diversi Dalam Pembaruan Sistem Peradilan Pidana Anak Di Indonesia. Genta Publishing. Yogyakarta.

Warassih, Esmi. 2011. Pranata Hukum Sebuah Telaah Sosiologis. PT. Suryandaru Utama. Semarang.

NN, Polisi Wajib Laksanakan Diversi dalam Peradilan Anak, http://yesfmcilacap.com/polisi_waj ib_laksanakan_diversi_dalam_per adilan_anak_berita3044.html, diakses pada tanggal 28 Desember 2014. 